\title{
Integrated provenance analysis of Carboniferous deposits from Northeastern Siberia: Implication for the late Paleozoic history of the Arctic
}

\author{
Victoria B. Ershova $^{\mathrm{a}, *}$, Andrei V. Prokopiev ${ }^{\mathrm{b}}$, Andrey K. Khudoley ${ }^{\mathrm{a}}$ \\ ${ }^{a}$ Institute of Earth Sciences, St. Petersburg State University, Universitetskaya nab. 7/9, St. Petersburg 199034, Russia \\ ${ }^{\mathrm{b}}$ Diamond and Precious Metal Geology Institute, Siberian Branch, Russian Academy of Sciences, Lenin av. 39, Yakutsk 677980, Russia
}

\section{A R T I C L E I N F O}

\section{Article history:}

Received 13 May 2014

Received in revised form 23 March 2015

Accepted 29 April 2015

Available online 15 May 2015

\section{Keywords:}

Siberian continent

Arctic

Carboniferous

Detrital zircon

Paleogeography

Provenance

\begin{abstract}
A B S T R A C T
An integrated provenance analysis based on sandstone petrography, distribution of REE and trace elements, and $\mathrm{U} / \mathrm{Pb}$ detrital zircon dating of Carboniferous sedimentary rocks of northern Verkhoyansk Fold and Thrust Belt (FTB) provides new insights into the tectonic evolution of NE Siberia. According to petrographic and geochemical data, Lower Visean sandstones had local provenance that contained mafic magmatic rocks. Wide distribution of ca. 2075 Ma detrital zircons known in the basement of neighboring Olenek and Ust'-Lena uplifts supports local provenance of the Lower Visean sandstones. Starting from Late Visean, clastic sediments have geochemical and petrographic compositions that are characteristic for erosion predominantly felsic rocks in a more remote source region. Detrital zircon age distributions in the Upper Visean - Upper Carboniferous sandstones, point to Taymyr - Severnaya Zemlya FTB and Central Asian Orogenic Belt (CAOB) as the most likely provenances for clastic rocks. However, wide distribution of Neoproterozoic and early Paleozoic detrital zircons that are not typical for synchronous CAOB-derived clastic rocks in the West Verkhoyansk, provide evidence for other than CAOB source area. We infer that the most likely source for Neoproterozoic - early Paleozoic detrital zircons in the Upper Visean - Upper Carboniferous sandstones is the Taimyr-Severnaya Zemlya FTB. The shift to sources from the Taimyr-Severnaya Zemlya FTB suggests an earlier (Late Visean) age for the collision between Kara terrane and Siberia than has been previously assumed (Late Carboniferous - Permian). Our paleogeographic restoration reveals the existence of two major fluvial systems draining eastward across the Siberian Craton during the Carboniferous: the Paleo-Lena in the south and the Paleo-Khatanga in the north.
\end{abstract}

(c) 2015 Elsevier Ltd. All rights reserved.

\section{Introduction}

The number of detrital zircon $\mathrm{U} / \mathrm{Pb}$ studies has increased dramatically in the past years, providing new constraints on the paleogeographic and tectonic evolution of sedimentary basins and their flanking continents. However, only a few $\mathrm{U} / \mathrm{Pb}$ detrital zircon studies have been carried out on the Paleozoic and Mesozoic successions of Siberia (Miller et al., 2006; Prokopiev et al., 2008; Miller et al., 2013; Harris et al., 2013).

This paper presents a provenance study of Carboniferous clastic strata deposited along the northern part of the Verkhoyansk passive margin of the Siberian continent (Figs. 1 and 2 show location of study). Preliminary data on the provenance of these sediments, based primarily on $\mathrm{U} / \mathrm{Pb}$ dating of detrital zircon populations, were presented in Ershova et al. (2013) and Prokopiev et al. (2013). Here

\footnotetext{
* Corresponding author.

E-mail address: ershovavictoria@gmail.com (V.B. Ershova).
}

we use an integrated provenance approach, including whole-rock geochemistry and sandstone petrography combined with the $\mathrm{U} / \mathrm{Pb}$ age distributions of detrital zircon populations. This more in depth study helps refine the nature of sediment source regions and leads to implications about the tectonic setting of both the sedimentary sequences studied as well as their surrounding landmasses.

The study area is located on the northeastern margin of the Siberian Craton in the Kharaulakh Anticlinorium (a northern segment of the Verkhoyansk FTB) near the Lena Delta and town of Tiksi (Figs. 1 and 2). The Siberian Craton forms the northeastern portion of the Eurasian plate and is bounded on all sides by fold belts of varying age, mainly the result of terrane accretion along the margins of Siberia during the Phanerozoic. The Verkhoyansk FTB was formed during the late Mesozoic collision of the Kolyma-Omolon Superterrane with the Siberian Craton (Parfenov, 1991). The Kharaulakh Anticlinorium consists of deformed Proterozoic to Mesozoic age sedimentary rock (Fig. 2a). Upper 


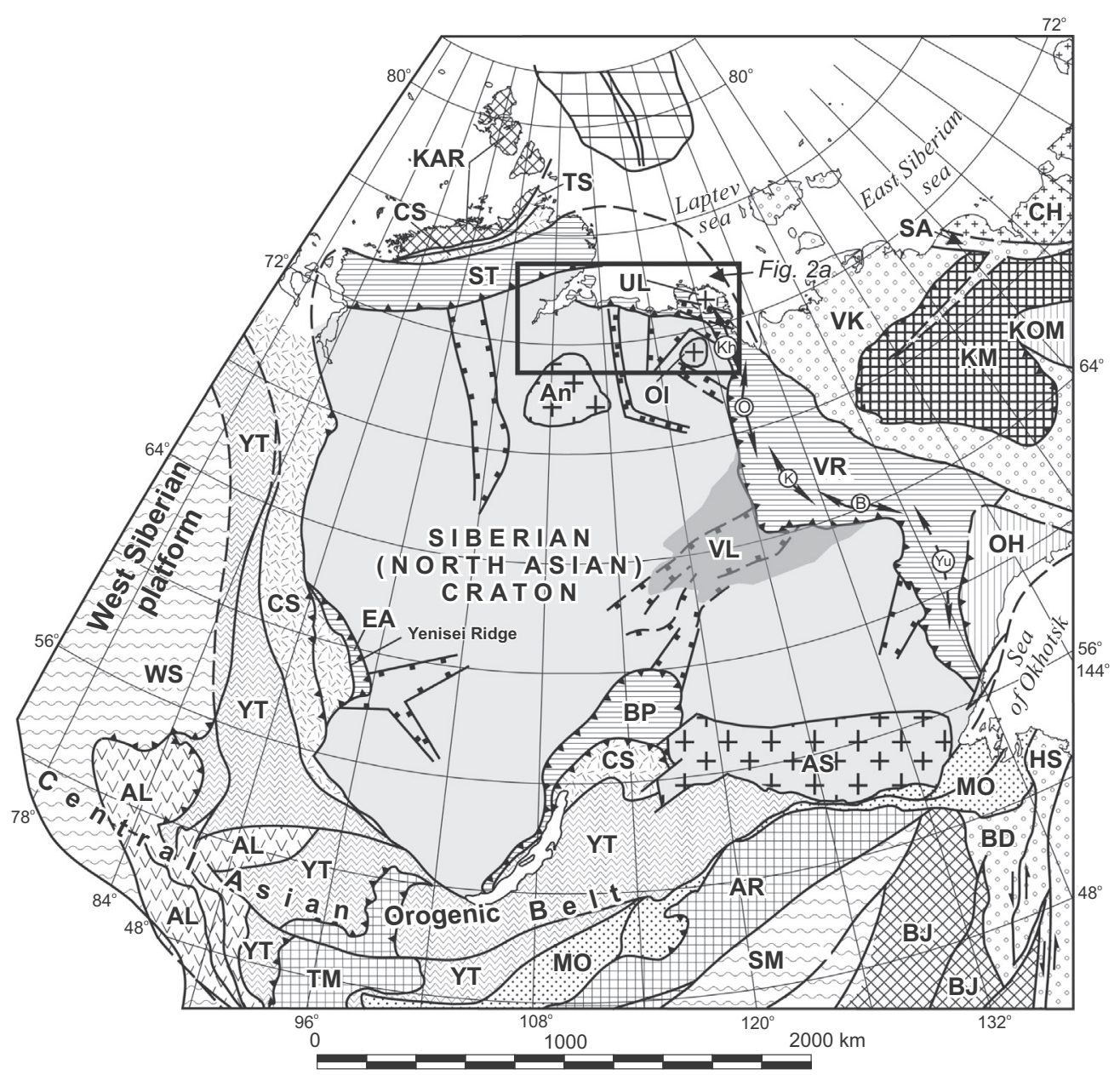

Siberian (North Asian) Craton

Shields and uplifts of the crystalline basement

Sedimentary cover

(An - Anabar Shield, AS - Aldan-Stanovoy Shield,

$L_{\perp}^{+-}$OI - Olenek Uplift, UI - Ust'-Lena Uplift)

Subsided craton margin - fold and-thrust belt (ST - South Taimyr, EA - East Angara, BP - Baikal-Patom, VR - Verkhoyansk)

Meso- and Neoproterozoic rifts

Middle-Paleozoic rifts (VL - Vilyui Basin)

Orogenic belts

Circum-Siberia (CS), Neoproterozoic

Yenisey-Transbaikal (YT) (Late

Cambrian to Early Ordovician)

al Mongol-Okhotsk (MO), Late Paleozoic-Early Mesozoic

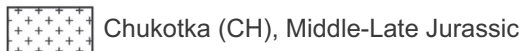

Altay (AL), Silurian

South Mongolia-Khingan (AM),

West Siberian (WS) and

Taimyr-Severnaya Zemlya (TS), Late Paleozoic

$\therefore$ Verkhoyansk-Kolyma (VK), South Anyui (SA),

$\therefore \because \therefore$ Honshu-Sikhote-Alin (HS), Late Jurassic-Early Cretaceous

艮冊冊 Kolyma-Omolon superterrane (KM)

Cratonal terranes: $\mathrm{OH}-$ Okhotsk,

KOM - Omolon

Fragments of Neoproterozoic orogenic belts:

TM - Tuva-Mongolia terrane and AR - Argun terrane

Fragments of Early Paleozoic orogenic

belts: BJ - Bureya-Jiamusi terrane and KAR - Kara terrane

Thrust

Anticlinorium (Kh - Kharaulakh,

Oceanic crust

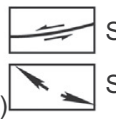

Strike-slip fault

Synclinorium (Yu - South Verkhoyansk).

Fig. 1. Map of cratons and orogenic belts of Northeast Asia (modified from Parfenov et al., 2003, 2009). 
Paleozoic - Upper Jurassic clastic strata deposited along the northeastern passive margin of Siberia are known as the Verkhoyansk Complex (e.g. Prokopiev et al., 2001 and references therein). Deposition of the Verkhoyansk Complex occurred in a set of delta-submarine fan systems related to craton-wide rivers and detrital zircons from the upper Paleozoic - Upper Jurassic sediments contain a record of magmatic and tectonic events in the
Siberian Craton and surrounding fold belts (Prokopiev et al. 2008; Ershova et al., 2013; Prokopiev et al., 2013).

\section{Overview of stratigraphy}

The basement of the Siberian Craton comprises a collage of Archean and early Paleoproterozoic terranes. The Archean terranes
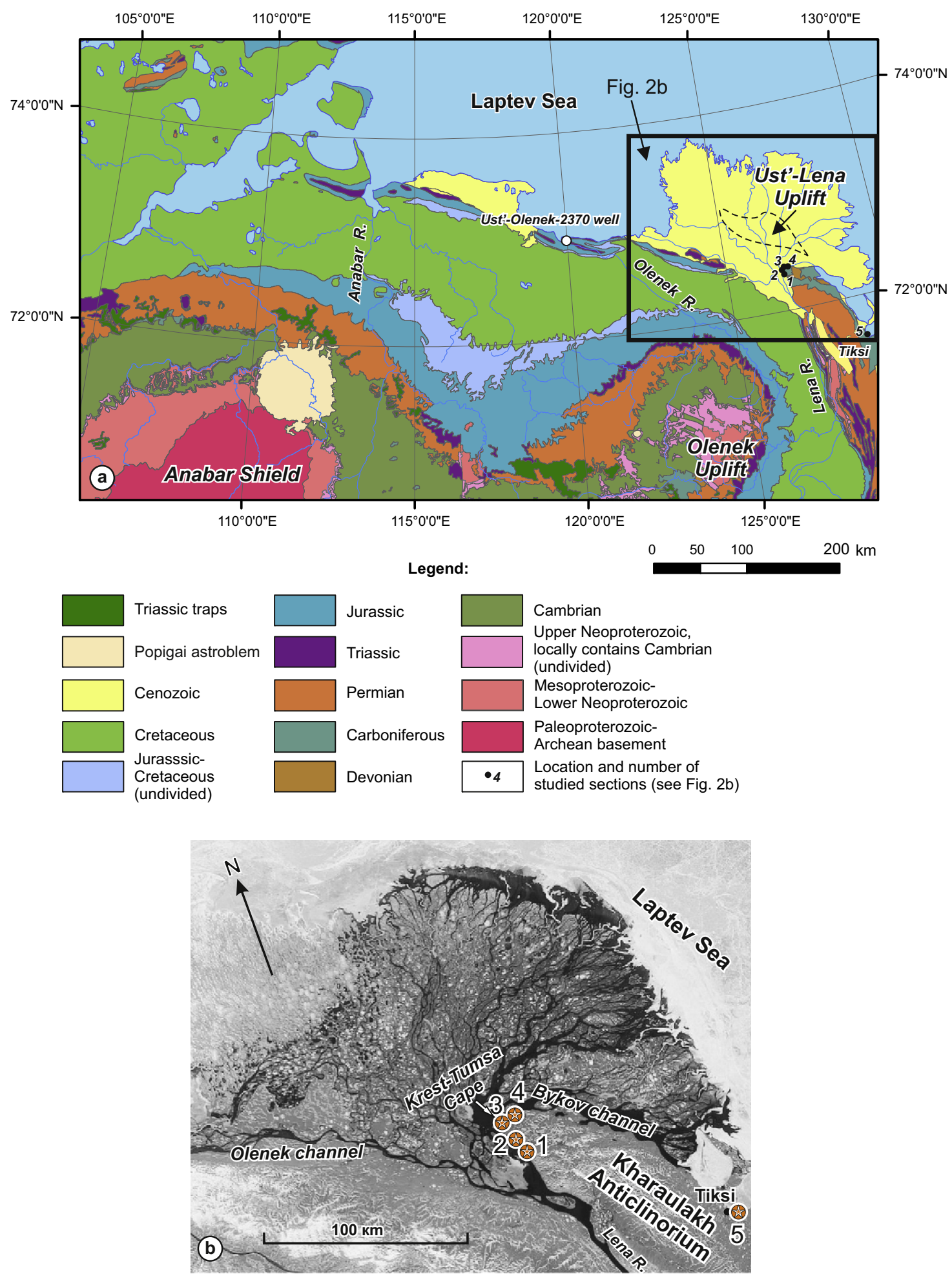

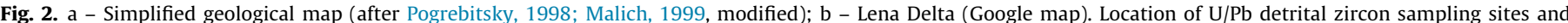

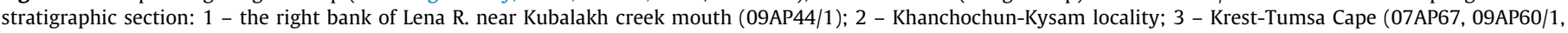
09AP73/1); 4 - Krest-Tumsa Cape (09AP55/1); 5- Tiksi Bay (07AP02). 
range mainly from 3.3 to $3 \mathrm{Ga}$ and the Paleoproterozoic terranes from 2.4 to 2.0 Ga (Rozen, 2003; Smelov and Timofeev, 2007). These terranes were amalgamated to form the Siberian Craton at 2.0-1.9 Ga. Younger ca. 1.9-1.8 Ga age rocks are also documented in the Siberian Craton basement and are most widespread in its southern part (Smelov and Timofeev, 2007).

The oldest sedimentary strata deposited in northeastern Siberia are Meso- and Neoproterozoic in age and overlie metamorphosed Archean-Paleoproterozoic basement with a significant hiatus. The Meso- and Neoproterozoic sedimentary succession contains numerous unconformities and is dominated by clastic rocks, although some thick carbonate units are also present (Prokopiev et al., 2001; Khudoley et al., 2015). The total thickness of the Mesoproterozoic succession varies from $400 \mathrm{~m}$ to more than $2000 \mathrm{~m}$. The uppermost Neoproterozoic part of the succession unconformably overlies various older Meso- and Neoproterozoic units as well as the Paleoproterozoic-Archean basement in the region of the Olenek Uplift and Anabar Shield. Uppermost Neoproterozoic sediments are also mainly clastic at their base but grade up to predominantly carbonates in the upper part of the succession. The thickness of the uppermost Neoproterozoic deposits varies from 300 to $400 \mathrm{~m}$ across the study area. The Cambrian successions of northern and northeastern Siberia are mostly carbonate rocks deposited in an epeiric sea, reaching a maximum thickness 600-700 m (Prokopiev et al., 2001).

Sedimentary rocks of Ordovician and Silurian age have a patchy distribution in the study area. The most complete section, comprising several hundred meters of dark grey and black clayey limestones, is penetrated by the Ust'-Olenek-2370 well located near the mouth of the Olenek River (Fig. 2a) (Grausman, 1995). Ordovician and Silurian rocks have also been described from a small fault-bounded unit in the northernmost part of the Kharaulakh Anticlinorium, and are found as pebbles in Visean conglomerate in the northwestern part of the anticlinorium (Bogush et al., 1963; Mezhvilk, 1956).

Lower Devonian strata have not been described from northeastern Siberia but Middle to Upper Devonian rocks are exposed at several locations in the western part of the Kharaulakh Anticlinorium and on a number of islands in the Lena River Delta (Menner and Sidyachenko, 1975; Prokopiev et al., 2001). Middle to Upper

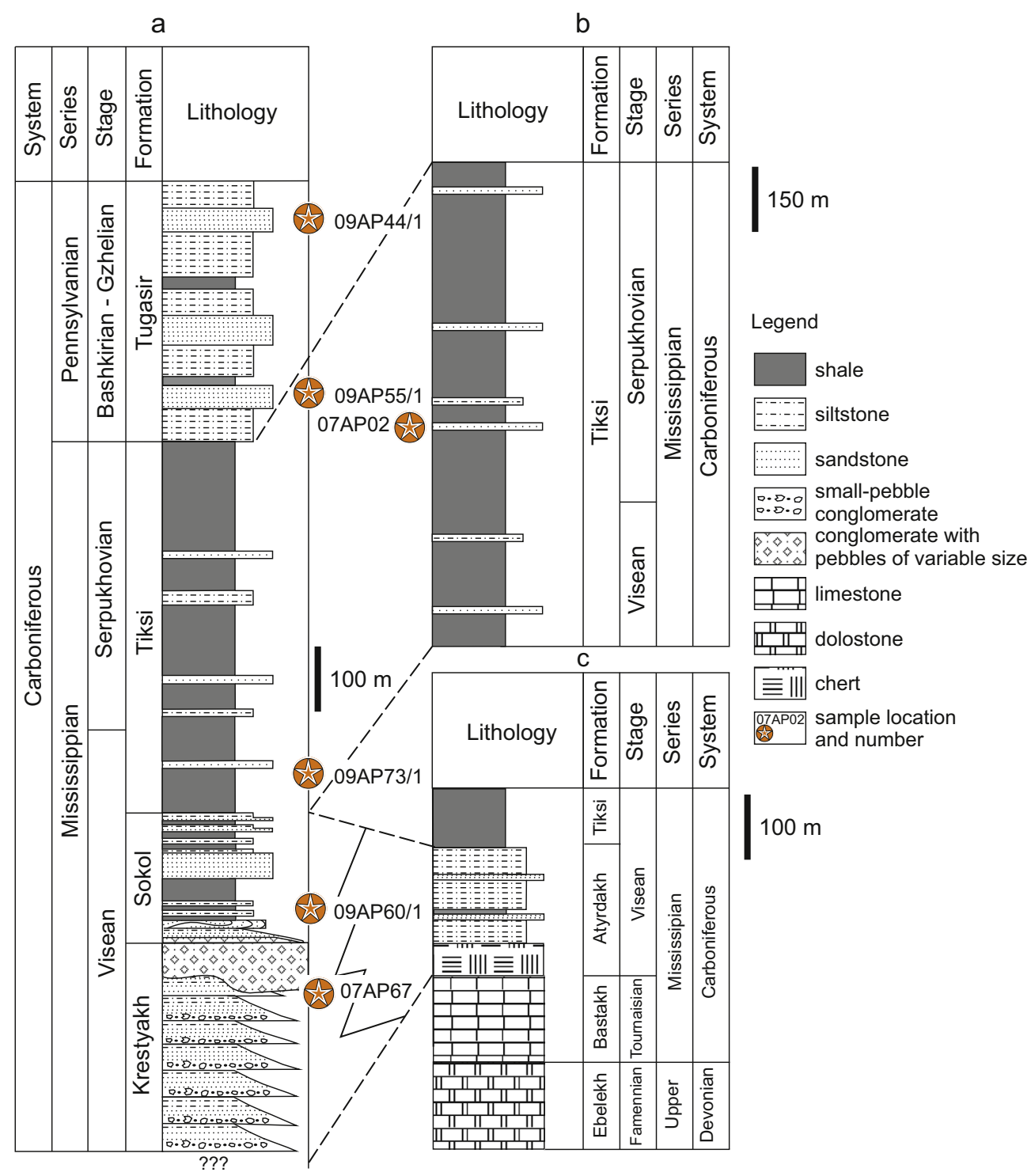

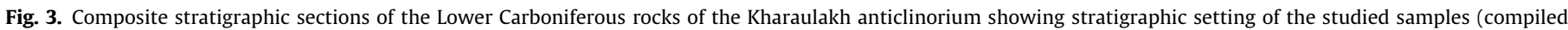

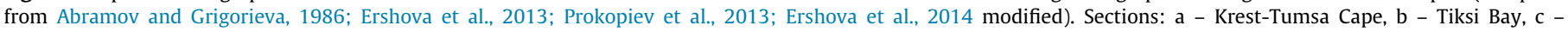
Khanchochun-Kysam locality (see location in Fig. 2). 
Devonian strata are represented by dolostones and dolomitized limestones, with interbedded sandstone in the upper part of the succession. Frasnian age basalt flows with a total thickness of up to $300 \mathrm{~m}$ occur in the middle part of the succession and are correlated with a middle Paleozoic (Late Devonian - Early Carboniferous) mafic magmatic and rifting event that affected the northeastern margin of Siberia (Prokopiev et al., 2001; Ershova et al., 2014).

The Carboniferous deposits, which are the focus of this study, are discussed in greater detail. Six formations are recognized: the Bastakh, Krestyakh, Sokol, Atyrdakh, Tiksi, and Tugasir formations (Figs. 2 and 3) (Abramov and Grigorieva, 1983, 1986).

The Bastakh Formation (Tournaisian) comprises a succession of bioclastic limestones with chert nodules up to $200 \mathrm{~m}$ thick, which conformably overlie Upper Devonian carbonates (Abramov and Grigorieva, 1986). In the studied section, the thickness of the Bastakh Formation was measured as $120 \mathrm{~m}$.

The Krestyakh Formation (Lower Visean) is mapped only in the northernmost part of the Kharaulakh Anticlinorium (Krest-Tumsa Cape and along Bykov Channel of the Lena River Delta (Fig. 2), comprising up to $300 \mathrm{~m}$ of mainly coarse to medium grained sandstone interbedded with conglomerates (Bulgakova, 1967; Ershova et al., 2014).

The Sokol Formation (Upper Visean) is mapped only on the Krest-Tumsa Cape where it conformably overlies the Krestyakh Formation (Fig. 2). The formation is represented mainly by coarse to medium grained sandstones at its base, grading upwards to siltstones and shale at the top of the succession. The total thickness of the formation in the study area is estimated as $150-200 \mathrm{~m}$.

The Atyrdakh Formation (Visean) is age equivalent to both the Krestyakh and Sokol formations and is widely distributed across the Kharaulakh Anticlinorium. The lower part of the succession is represented by chert up to $40 \mathrm{~m}$ thick, which is overlain by a $150-200 \mathrm{~m}$ thick unit of interbedded sandstones, siltstones and shales.

The Tiksi Formation (uppermost Visean - Serpukhovian) comprises a succession of shales with occasional thin sandstone and siltstone beds with a total thickness that varies from 600 to $900 \mathrm{~m}$ (Abramov and Grigorieva, 1986). In the studied section, the thickness of the Tiksi Formation varied from 550 to $700 \mathrm{~m}$.

The Tugasir Formation (Middle-Upper Carboniferous) is represented by a succession of shales, siltstones and sandstones with a total thickness of up to $1 \mathrm{~km}$ (Abramov and Grigorieva, 1983). In the study area we estimated its total thickness as about $400 \mathrm{~m}$.

\section{Sandstone petrography}

Twenty thin sections were point-counted using the Gazzi-Dickinson method (Gazzi, 1966; Dickinson, 1970; Ingersoll et al., 1984). The complete results of these analyses are presented in Supplementary Table 1 and in Fig. 4 and are summarized below.

\subsection{Krestyakh formation}

Sandstones of the Krestyakh Formation are defined as poorly sorted lithic arkoses and sublitharenites, with an overall average composition of quartz (Q) $55 \%$, feldspar (F) $21 \%$ and lithic (L) $24 \%$ fragments (Fig. 4a). Quartz grains are the most abundant constituent, comprising $38-67 \%$ of the population. Monocrystalline quartz predominates but polycrystalline quartz grains are present in minor amounts, comprising only $1-2 \%$ of the quartz grains. Feldspar constitutes $16-29 \%$ of the framework grains and varies significantly in shape and size.

Lithic fragments comprise $16-39 \%$ of the grains and are mostly medium- or coarse-grained, sub-rounded, rounded to angular. Shale and carbonate lithic fragments are the most typical. Carbonate grains constitute $90-95 \%$ of the total lithic grains, while shale clasts are rare and constitute no more than $1-2 \%$ of the total lithic grains. In addition, mafic volcanic rocks and schist comprise a few percent of the total lithic fragments.

\subsection{Sokol formation}

Sandstone of the Sokol Formation is similar in composition to the Krestyakh Formation, with an overall average composition of quartz (Q) 55\%, feldspar (F) 26\% and lithic (L) 19\% fragments (Fig. 4a). Quartz comprises $42-65 \%$ of the rock's framework grains, which are represented mainly by monocrystalline quartz grains. Feldspar comprises $12-30 \%$ of the grains. Both quartz and feldspar grains are sub-angular to sub-rounded. Lithic grains are largely composed of rounded to sub-angular fragments of volcanic rocks (mainly basalts) and fragments of sedimentary rocks (mainly carbonates with rare shale).

\subsection{Tiksi formation}

Sandstones of the Tiksi Formation are very fine-grained arkoses with an overall average composition of quartz (Q) $59 \%$, feldspar (F) $39 \%$ and lithic (L) $2 \%$ fragments (Fig. 4a). In contrast to the
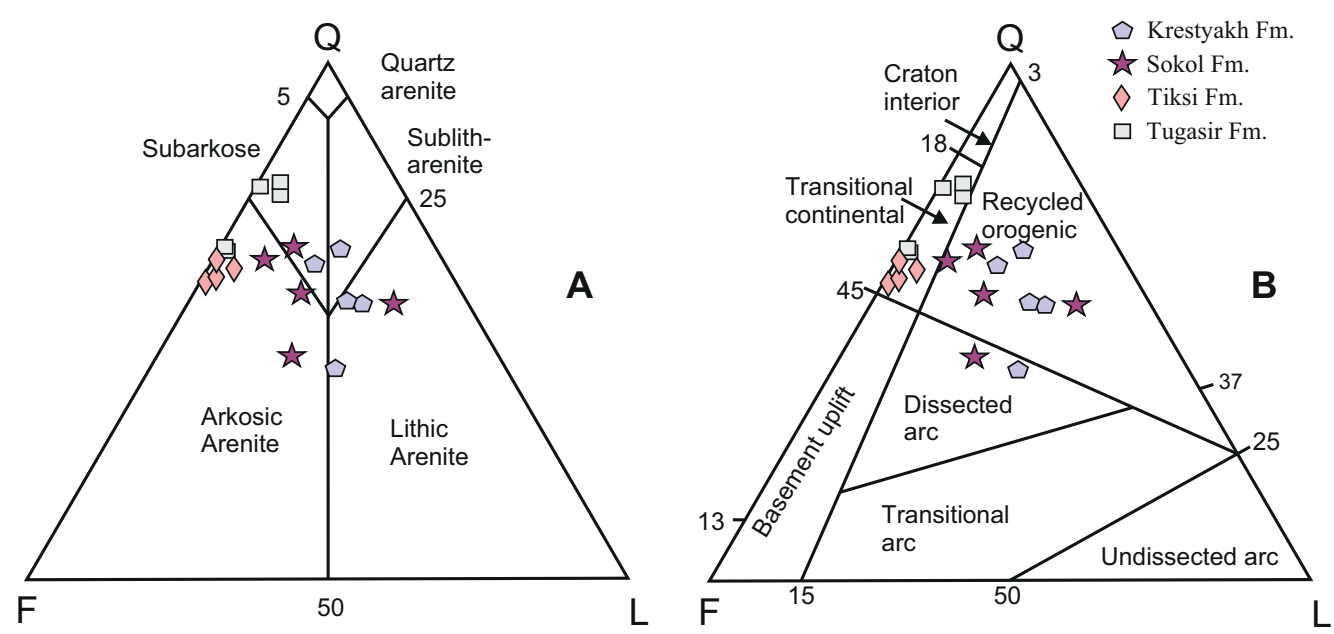

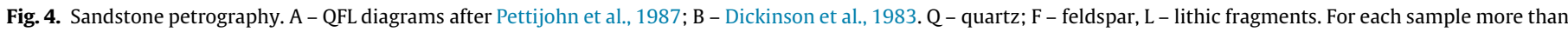
300 grains were counted and categorized. 
underlying sandstones, the arkoses have fewer lithic fragments. The grains range from sub-angular to sub-rounded.

\subsection{Tugasir formation}

Most sandstones within the Tugasir Formation are subarkoses, with grains consisting of quartz (Q) 70\%, feldspar (F) 27\% and lithic (L) $3 \%$ fragments (Fig. 4a). The lithic fragments are composed predominantly of carbonate and schist. The sandstones are fine- to medium-grained, ranging from moderately to well sorted and dominated by sub-angular to sub-rounded grains.

\section{Whole-rock geochemistry}

According to McLennan et al. (1993, 2003) geochemical approach is important in provenance studies as key trace element ratios are sensitive in identifying minor components that are not readily recognized petrographically, but are characteristic for provenance composition. Whole-rock geochemistry was determined for nine samples from the Krestyakh Formation, three samples from the Sokol Formation, three samples from the Tiksi Formation, and eight samples from the Tugasir Formation.

Chemical studies were done at the All Russian Geological Research Institute (VSEGEI) in St. Petersburg. Whole-rock major element concentrations were determined by XRF method using ARL 9800 spectrometer, whereas trace and rare earth elements (REE) were determined by Inductively Coupled Plasma-Mass Spectrometry (ICP-MS) using an Optima 4300DV emission spectrometer and an ELAN 6100 DRC mass spectrometer. The measured concentrations of major, trace and REE elements are listed in Supplementary Table 2. All measured concentrations are far above detection limits, with analytical uncertainties of less than $5 \%$ for major elements and $4-10 \%$ for trace and rare earth elements except for $\mathrm{Ni}$, which has an uncertainty of $\sim 15 \%$. Specific elements and their ratios (REE, Th, Sc, Zr, Co) are selected in accordance with approach by McLennan et al. (1993, 2003). However, very high variation of L.O.I. (from $1.75 \%$ to $26.4 \%$ ) makes interpretation of the major elements ambiguous and we exclude them from discussion.

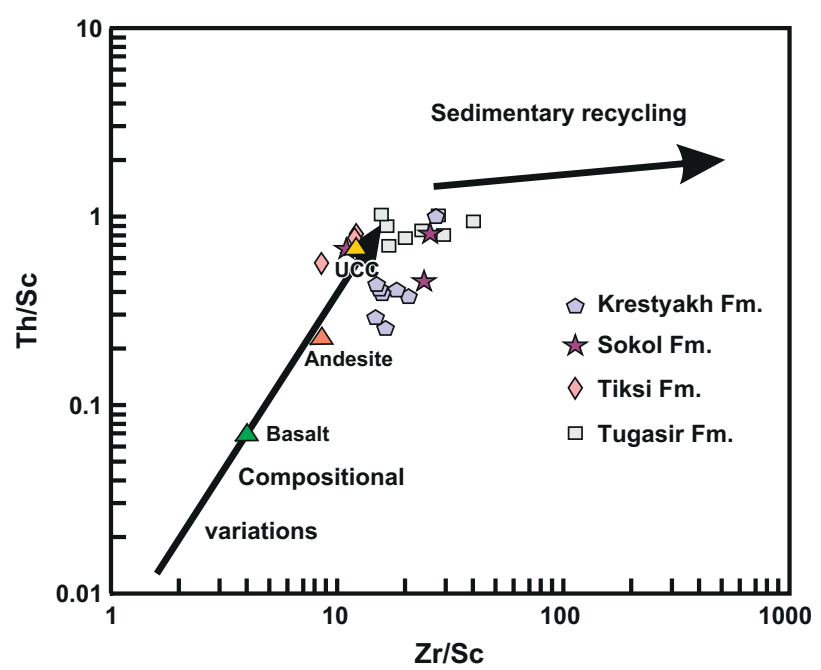

Fig. 5. $\mathrm{Zr} / \mathrm{Sc}$ versus $\mathrm{Th} / \mathrm{Sc}$ diagram. The $\mathrm{Th} / \mathrm{Sc}$ ratio is a sensitive indicator of igneous chemical differentiation processes because Th is an incompatible element whereas $\mathrm{Sc}$ is compatible. The $\mathrm{Zr}$ content reflects the abundance of heavy minerals, notably zircon, and therefore is used as a proxy for sedimentary sorting and recycling (McLennan et al., 1993, 2003). Average compositions of the upper continental crust (UCC) and Mesozoic - Cenozoic andesite and basalt are from Condie (1993).
Although variations of both $\mathrm{Th} / \mathrm{Sc}$ and $\mathrm{Zr} / \mathrm{Sc}$ ratios are not very significant, samples from different formations occupy different fields on the diagram (Fig. 5). All samples from the Krestyakh Formation have the lowest $\mathrm{Th} / \mathrm{Sc}$ ratios and are located in a small field. Alternately, sediments of the Tiksi and Tugasir formations have similar $\mathrm{Th} / \mathrm{Sc}$ ratios but variable $\mathrm{Zr} / \mathrm{Sc}$ ratios. The Sokol Formation samples show transitional patterns between samples from Krestyakh and Tiksi and Tugasir formations.

Significant differences are between the REE distributions in clastic rocks of the Krestyakh Formation and the Tiksi and Tugasir formations, while deposits of the Sokol Formation show intermediate characteristics (Fig. 6). The clastic rocks of the Tugasir and Tiksi formations are characterized by LREE enrichment with average ( $\mathrm{La} / \mathrm{Lu}) \mathrm{n}$ ratio of 9.7 and 8.6. Average values of the Eu anomaly range from 0.59 to 0.66 for the Tiksi and Tugasir formations respectively. By contrast, clastic rocks of the Krestyakh
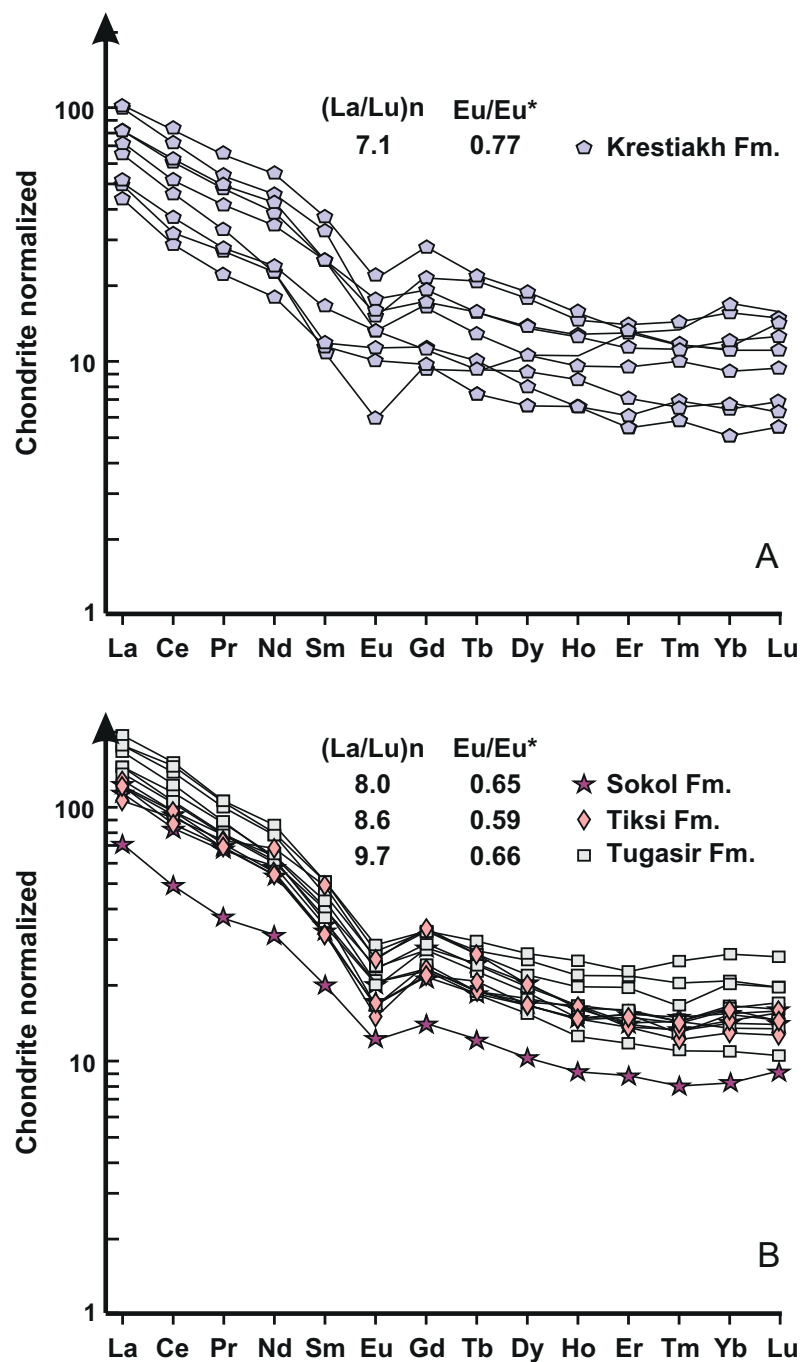

Fig. 6. Rare earth element distribution of studied samples (chondrite normalized after Taylor and McLennan, 1985). A - Krestyakh Formation, B - Sokol, Tiksi and Tugasir formations. Eu/Eu* is Europium anomaly, where Eu is measured concentration of Europium, and $\mathrm{Eu}^{*}$ is its theoretical concentration calculated as geometric mean of Sm and Gd concentrations assuming no chondrite-normalized Eu anomaly (Condie, 1993). ( $\mathrm{La} / \mathrm{Lu}) \mathrm{n}$ is chondrite normalized ratio of La to Lu concentrations and shows enrichment of light REE over heavy REE. REE distribution is sensitive to the composition of igneous rocks in provenance and these elements are least affected by sedimentary or post-depositional processes (Taylor and McLennan, 1985; McLennan, 1989). Both (La/Lu)n and Eu/Eu* varies greatly in magmatic rocks, but in felsic rocks $(\mathrm{La} / \mathrm{Lu}) \mathrm{n}$ is higher than in mafic rocks, whereas $\mathrm{Eu} / \mathrm{Eu}^{*}$ is higher in mafic rocks (e.g. Taylor and McLennan, 1985; Condie, 1993). 


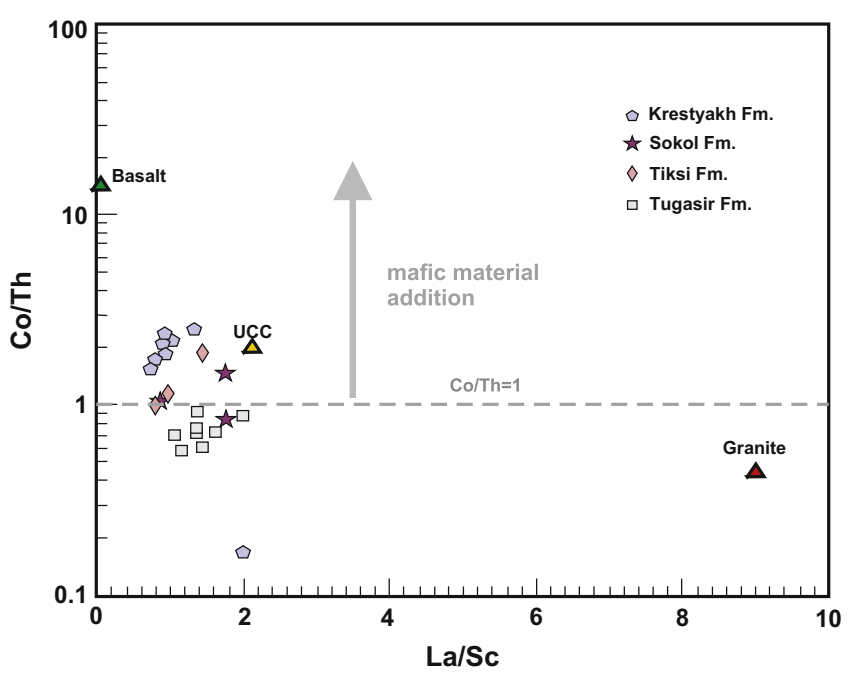

Fig. 7. La/Sc versus $\mathrm{Co} / \mathrm{Th}$ diagram shows ratios between compatible and incompatible elements that are sensitive to igneous chemical differentiation processes and represent composition of rocks in provenance (Taylor and McLennan, 1985; Khudoley et al., 2001; Gu et al., 2002). Average compositions of upper continental crust (UCC), Phanerozoic granite and Mesozoic - Cenozoic basalt are from Condie (1993).

Formation show relatively low LREE enrichment with an average $(\mathrm{La} / \mathrm{Lu}) \mathrm{n}$ ratio of 7.1 and Eu anomaly of 0.77 .

All but one of the samples from the Krestyakh Formation has a $\mathrm{Co} / \mathrm{Th}$ ratio that is significantly higher than that of the Tugasir Formation (Fig. 7). Samples from Sokol and Tiksi formations occupy fields transitional between those of Krestyakh and Tugasir formations. Samples from all formations have quite close values of $\mathrm{La} / \mathrm{Sc}$ ratio.

\section{Detrital zircon $\mathrm{U}-\mathrm{Pb}$ geochronology}

Geochronological studies were carried out on six samples collected at three localities within the northern part of the Kharaulakh Anticlinorium (Figs. 2 and 3). Four samples (07AP67 from Krestyakh Formation, 09AP60/1 from Sokol Formation, 09AP73/1 from Tiksi Formation and 09AP55/1 from Tugasir Formation) were collected at Cape Krest-Tumsa. Sample 07AP02 (Tiksi Formation) was collected from an outcrop along Tiksi Bay; and sample 09AP44/1 (Tugasir Formation) was collected on the right bank of the Lena River near the mouth of Kubalakh Creek (Fig. 2).

Samples were crushed and heavy minerals were concentrated using standard techniques at the Institute of Precambrian Geology RAS and Diamond and Precious Metal Geology Institute SB RAS. The zircon grains were mounted in epoxy and polished. $\mathrm{U} / \mathrm{Pb}$ analyses of samples 09AP44/1, 09AP55/1, 09AP60/1, 09AP73/1 were carried out by the Apatite to Zircon, Inc. Material for samples 07AP02 and 07AP67 were supplied by A.V. Prokopiev to E.L. Miller at Stanford University and analyzed at the LaserChron Center supervised by G. Gehrels. Data tables and a description of analytical procedures are provided in Supplementary Tables 3a, b and accompanying text. At least 100 grains were selected for analysis in a random fashion in each sample. ${ }^{207} \mathrm{~Pb} /{ }^{206} \mathrm{~Pb}$ ages are reported for zircons $>1.0 \mathrm{Gas}$ and ${ }^{206} \mathrm{~Pb} /{ }^{238} \mathrm{U}$ ages for zircons $\leqslant 1.0 \mathrm{Ga}$. Following Gehrels (2012), only analyses with discordance between $30 \%$ and $-10 \%$ were used for interpreting the data. Detrital zircon age information is shown on probability density plots in Fig. 8. The majority of detrital zircons from the studied samples exhibit low U/Th ratios, indicating a magmatic source (Gehrels et al., 2008) (Fig. 9). Magmatic origin of most zircons makes possible to correlate them with age of magmatic rocks for provenance interpretation.

\subsection{AP67 (Krestyakh Formation)}

Sixty percent of all analyzed grains are Precambrian in age, with the oldest Archean grains dating from 3.2 to $2.5 \mathrm{Ga}$ and forming a minor peak at $2.55 \mathrm{Ga}$ (Fig. 8). Paleoproterozoic grains contribute $52 \%$ of the total population and form a major peak at $2075 \mathrm{Ma}$. The Paleozoic grains are grouped around three peaks at ca. 400, 390 and $365 \mathrm{Ma}$.

\subsection{AP60/1 (Sokol Formation)}

Forty-five percent of the dated grains are Precambrian in age (Fig. 8). The few Archean grains are grouped around $2500 \mathrm{Ma}$ while Paleoproterozoic grains contribute $20 \%$ of the total population and form a major peak at $1875 \mathrm{Ma}$. Neoproterozoic zircons form a peak at $810 \mathrm{Ma}$. The Paleozoic grains comprise $55 \%$ of the total population and have three peaks at ca. 485, 360 and $335 \mathrm{Ma}$.

\subsection{AP73/1 (Tiksi Formation)}

Fifty-seven percent of the dated zircons are of Precambrian age (Fig. 8). Archean grains comprise 9\% of the total population and range between 2600 and $2400 \mathrm{Ma}$. Paleoproterozoic zircons comprise $16 \%$ of the total population with most ages concentrated between 1800 and 1900 Ma. Neoproterozoic grains are predominant and grouped in peaks at ca. 800, 705 and $610 \mathrm{Ma}$. The Paleozoic grains are grouped in 3 major peaks at ca 470, 395 and $335 \mathrm{Ma}$. The $335 \mathrm{Ma}$ peak is close to the depositional age of the formation.

\subsection{AP02 (Tiksi Formation)}

Fifty-two percent of the dated grains are of Precambrian age (Fig. 8). The few Archean grains are grouped around $2500 \mathrm{Ma}$, whilst while Paleoproterozoic grains contribute $25 \%$ of the total population and form a peak at 1985 Ma. Neoproterozoic grains are grouped in several peaks at 830 and $755 \mathrm{Ma}$. Paleozoic zircons comprise $48 \%$ of the total population and are grouped around 500 , 385 and $345 \mathrm{Ma}$, with minor populations at ca. 520 and $420 \mathrm{Ma}$.

\subsection{AP55/1 (Tugasir Formation)}

Seventy-three percent of the dated grains are Precambrian in age (Fig. 8). Archean grains comprise $7 \%$ of all dated zircons with dominant ages of 2600-2500 Ma. Paleoproterozoic and Neoproterozoic grains comprise $36 \%$ and $30 \%$ of the total population respectively, with Paleoproterozoic zircons having a major peak around $1850 \mathrm{Ma}$ and Neoproterozoic zircons forming two peaks at 690 and $580 \mathrm{Ma}$. Paleozoic grains are grouped in two major populations, including Early Ordovician with a peak ca. $485 \mathrm{Ma}$, and Late Devonian - Early Carboniferous with a peak at ca. $360 \mathrm{Ma}$.

\subsection{AP44/1 (Tugasir Formation)}

The sample is dominated by Precambrian zircons (72\%) (Fig. 8). Archean age grains range from 3200 to $2500 \mathrm{Ma}$, making up $11 \%$ of all dated grains. Paleoproterozoic grains (27\%) form a distinct peak around $1835 \mathrm{Ma}$. Neoproterozoic grains (34\%) are grouped in two populations with peaks at 800 and $625 \mathrm{Ma}$. Paleozoic zircons form two peaks ca. $500 \mathrm{Ma}$ and $315 \mathrm{Ma}$, the latter being close to the age of the formation. 

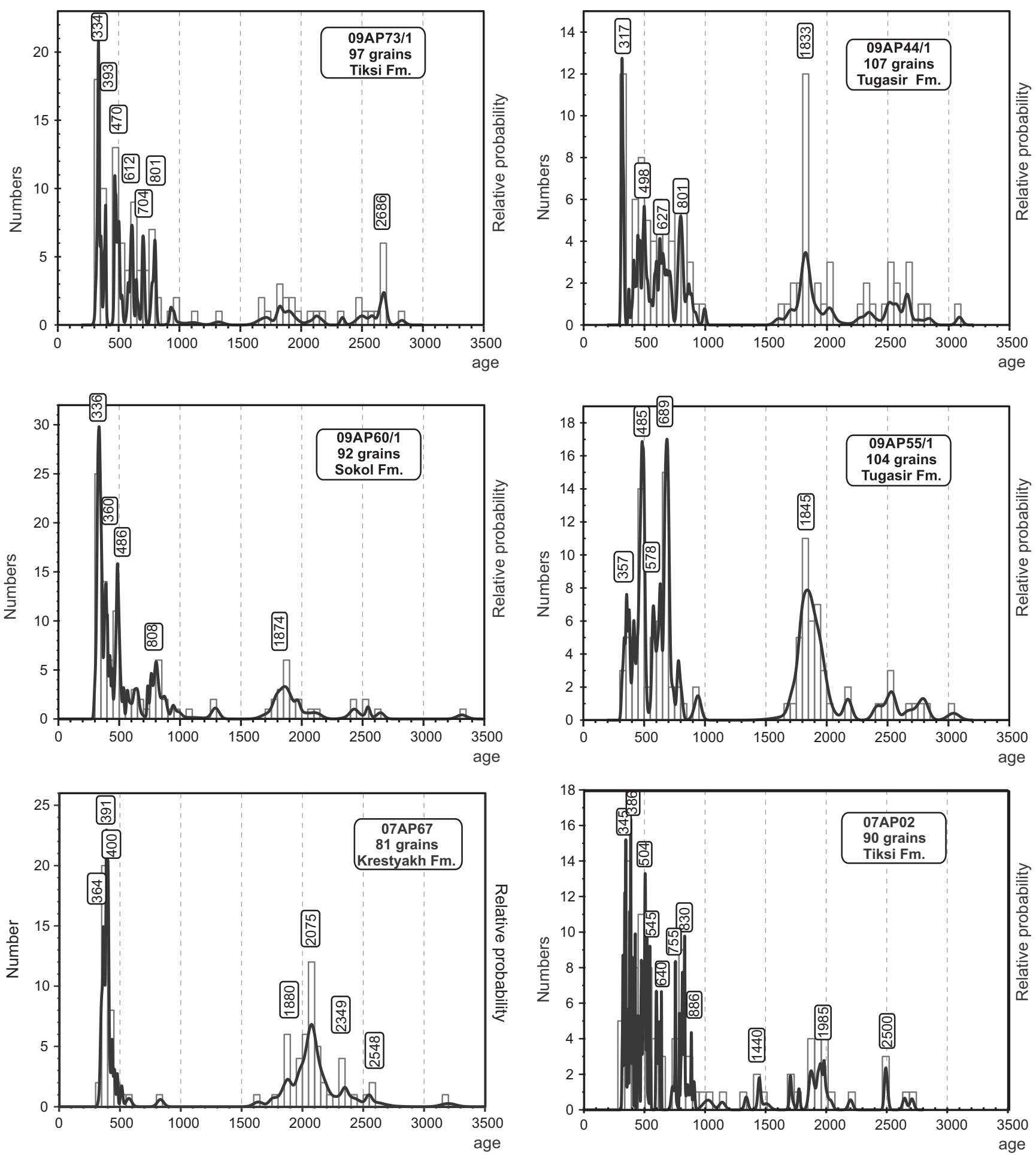

Fig. 8. Histograms and normalized age probability plots for studied samples.

\section{Discussion}

\subsection{Provenance interpretation}

The provenance interpretation presented here is based on $\mathrm{U}-\mathrm{Pb}$ detrital zircon data which provides information on the age of magmatic rocks in the source region, and on petrographic and geochemical studies which provide information on the composition of rocks in source region.
The most contrasting geochemical and petrographic characteristics are those from sandstones from the Krestyakh versus those from the Tiksi and Tugasir formations. Sandstones from the Tiksi and Tugasir formation have the highest $\mathrm{Th} / \mathrm{Sc}$ and $(\mathrm{La} / \mathrm{Lu}) \mathrm{n}$ ratios and Eu anomalies (Figs. 5 and 6), typical of clastic rocks eroded from predominantly felsic rocks. Their location in the transitional continental field on the Dickinson et al. (1983) diagram (Fig. 4b) supports predominant erosion of felsic rocks. In contrast, sandstones from the Krestyakh Formation have the lowest Th/Sc and 


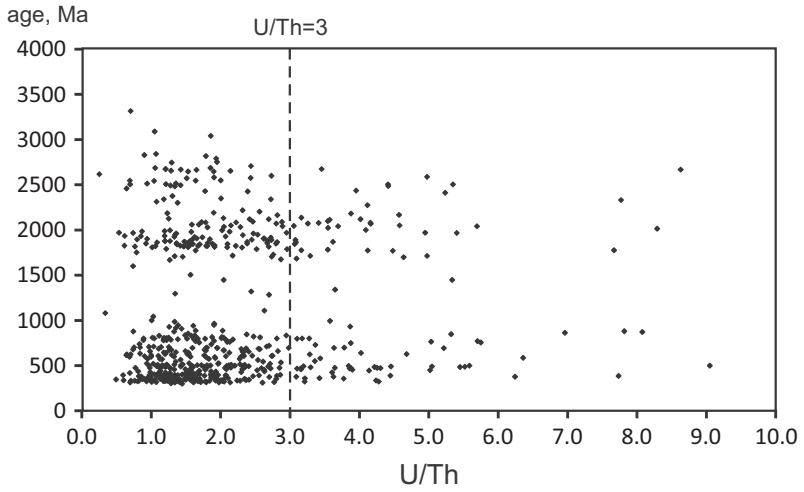

Fig. 9. $U /$ Th ratios indicating the magmatic source for most zircons $(U / T h<3$, after Gehrels et al., 2008).

(La/Lu)n ratios and Eu anomalies (Figs. 5 and 6) likely pointing to increasing erosion of mafic rocks. Occurrence of rare mafic volcanic clasts in sandstones from the Krestyakh Formation supports this interpretation. Sandstones from the Sokol Formation typically occupy a transitional field between those of sandstones from the Krestyakh and those of the Tiksi and Tugasir formations.

The U-Pb detrital zircon's ages from Krestyakh sandstones show a wide range of Paleoproterozoic grains with a major peak at $2075 \mathrm{Ma}$. Close in age basement rocks have been reported from the Ust'-Lena and Olenek uplifts showing possible location of local provenance for sandstones from the Krestyakh Formation (Prokopiev et al., 2007; Wingate et al., 2009). The second largest population of Devonian detrital zircons has ages similar to those of magmatic rocks that are attributed to middle Paleozoic rifting affected eastern margin of Siberia (Gaiduk, 1988; Prokopiev et al., 2001). The low $\mathrm{Zr} / \mathrm{Sc}$ ratios and occurrence of unstable mafic volcanic lithic clasts in both sandstones and conglomerates of the Krestyakh Formation sandstones (e.g. Prokopiev et al., 2013; Ershova et al., 2014) suggests they are likely to have been derived from local uplifts which would have resulted in weathering of a Proterozoic-Lower Carboniferous (Tournaisian) predominantly carbonate succession with interlayered units of Devonian basalt, explaining both the abundance of carbonate grains and presence of mafic volcanic rock fragments in the sandstones of the Krestyakh Formation.

A notable shift in the location of the provenance area occurred in the Late Visean. Our results suggest that the Sokol, Tiksi and Tugasir formations illustrate significantly different provenance signatures compared to the Early Visean clastics of the Krestyakh Formation. The sandstone petrographic analyses reveal decreasing proportions of unstable lithic grains upwards in the Carboniferous section. Sandstones from the Tiksi and Tugasir formations have similar Th/Sc, La/Sc and Co/Th ratios showing that they were derived from rocks of similar composition (Figs. 5 and 7). However, the variations in their $\mathrm{Zr} / \mathrm{Sc}$ ratios, show increasing influence of sedimentary recycling or sorting on the sandstone composition (Fig. 5). According to McLennan et al. (1993, 2003), both sedimentary sorting and recycling result in an enrichment of heavy minerals like zircon and a correspondent increase in $\mathrm{Zr} / \mathrm{Sc}$ ratios. However, significant differences in the $\mathrm{U}-\mathrm{Pb}$ detrital zircon age distributions of the Tiksi and Tugasir Formations suggest that it is unlikely that they contain significant portions of recycled Krestyakh Formation sandstones. Therefore, we infer that increasing of $\mathrm{Zr} / \mathrm{Sc}$ ratio in sandstones from the Tiksi and Tugasir formations reflect longer transport and sedimentary sorting rather than recycling. Thus, geochemical data suggest a longer sediment transport distance from source to sink, although some sediment reworking may occur as well.
The distribution of detrital zircon ages from the Sokol, Tiksi and Tugasir formations sandstones is quite similar. The $1.8-1.85 \mathrm{Ga}$ Paleoproterozoic ages are prevalent which differs from the sandstones of the Krestyakh Formation. Although rocks of this age are known within the basement rocks of the Anabar Shield (Gusev et al., 2013) they are more widespread across the southern and southwestern margins of Siberian Craton (Smelov and Timofeev, 2007; Prokopiev et al., 2008). The diagnostic feature of the Upper Visean - Upper Carboniferous samples is that they contain a significant proportion of Neoproterozoic-Paleozoic aged zircons, clearly pointing to a provenance outside of the Siberian Craton. Close in age Neoproterozoic and Paleozoic magmatic rocks are abundant in Taimyr-Severnaya Zemlya FTB (Fig. 10a and b) (Vernikovsky, 1996; Vernikovsky and Vernikovskaya, 2001; Vernikovsky et al., 2004; Lorenz et al., 2007, 2008) and CAOB (Vernikovsky et al., 2004; Windley et al., 2007; Safonova et al., 2011; Rudnev, 2013; Glorie et al., 2011, 2014; Kröner et al., 2014; Rohas-Agramonte et al., 2011, 2014), extending along the northern and southern margins of Siberia respectively and showing possible source regions.

Furthermore, the CAOB was considered previously as a provenance area for upper Paleozoic-Jurassic samples collected further south along the Verkhoyansk passive margin (Prokopiev et al., 2008). A comparison of our Upper Visean - Upper Carboniferous samples with an Upper Carboniferous sample dated previously

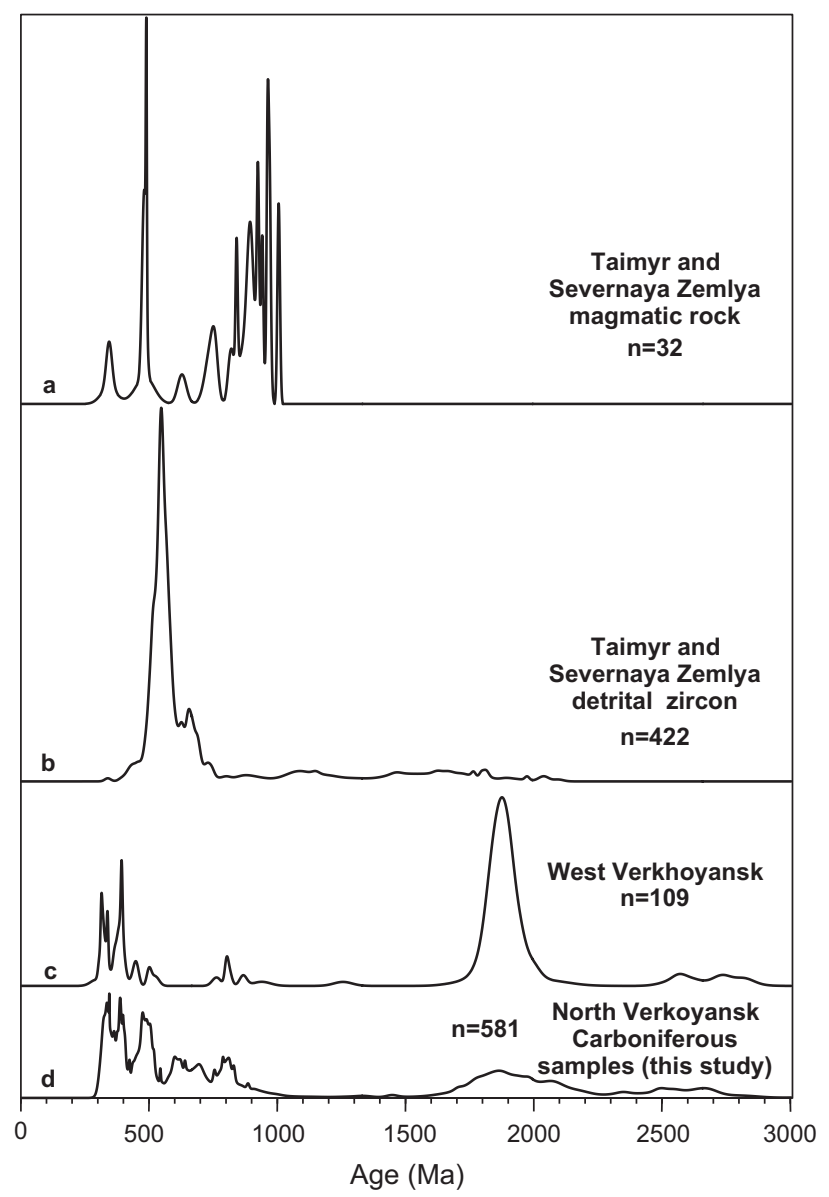

Fig. 10. Comparison of relative age probability distributions: a - Taimyr and Severnaya Zemlya magmatic rock (Pease and Scott, 2009; Pease et al., 2001; Vernikovsky et al., 2001; Zakharov et al., 1993; Vernikovsky et al., 2004; Vernikovsky, 1996; Pease and Vernikovsky, 1998; Lorenz et al., 2007); b - Taimyr and Severnaya Zemlya detrital zircon (Pease and Scott, 2009; Lorenz et al., 2008); c - detrital zircons from Upper Carboniferous sample from West Verkhoyansk (Prokopiev et al., 2008); d - detrital zircons from Carboniferous deposits of North Verkhoyansk passive margin (this study). 
by Prokopiev et al. (2008) shows a significant difference in the detrital zircon age distribution (Fig. 10c and d). Both sample's dataset have a $1800-1850 \mathrm{Ma}$ population and Late Devonian-Carboniferous grains. However, the Neoproterozoic and early Paleozoic zircons, which contribute up to $80 \%$ of the population in our samples (Fig. 8), contribute less than $8 \%$ in the Upper Carboniferous sample of Prokopiev et al. (2008). The Neoproterozoic signature with peaks at 600-650 and 700$750 \mathrm{Ma}$ is very strong in our samples from the northern part of the Verkhoyansk passive margin, yet would appear to be absent from rocks of the same age further south along the passive margin (Fig. 10c). We interpret these differences in zircon age distributions to reflect different provenances for the Upper Visean-Upper Carboniferous clastics deposited along the northern and central parts of the Verkhoyansk passive margin of Siberia respectively.

The key issue involved with the identification of the provenance area for the Upper Visean - Upper Carboniferous deposits is to locate the source of the Neoproterozoic and Paleozoic zircons. Paleozoic ages are also reported as both detrital grains and magmatic ages from Taimyr and Severnaya Zemlya (Lorenz et al., 2007, 2008; Pease and Scott, 2009). The 475-490 Ma (Early Ordovician) intrusive and volcanic rocks, along with Early Carboniferous granites, have been studied from October Revolution Island in the northern part of the Kara terrane (part of the Taimyr-Severnaya Zemlya FTB) (Lorenz et al., 2007; Makariev, 2013). Therefore, a suite of Neoproterozoic-middle Paleozoic rocks exposed on the Taimyr Peninsula and Severnaya Zemlya could represent the source for the Neoproterozoic and Paleozoic zircons observed in the studied samples from the northern part of the Verkhoyansk passive margin. The presence of 1800-1850 Ma zircons within dated samples also show a possible contribution clastics from the western and southwestern margins of Siberia.

\subsection{Paleotectonic implication}

Thus, we suggest that the most likely provenance areas for the studied Upper Visean - Upper Carboniferous succession were located within the Taimyr-Severnaya Zemlya FTB and CAOB. A number of previous studies have concluded that collision between the Kara terrane and Siberian Craton occurred in the Late Carboniferous-Permian (Metelkin et al., 2005; Cocks and Torsvik, 2007). The Kara terrane comprises Severnaya Zemlya Archipelago, Northern Taimyr and adjacent regions of Kara Sea and interpreted as a separate tectonic block in the Paleozoic (Metelkin et al., 2005; Cocks and Torsvik, 2007). However, syncollisional Early Carboniferous granites (342-343 Ma) present on Severnaya Zemlya archipelago (Lorenz et al., 2007) and reported from northern Taimyr and adjacent islands (ages range from 317 to 344) (Makariev, 2013) suggesting that collision between Kara terrane and Siberia may have occurred earlier. These granites could be a potential source of the Carboniferous zircons, which are roughly coeval with the age of our Upper Visean - Upper Carboniferous formations (Fig. 8). The distribution of detrital zircons from the studied Carboniferous deposits shows that the Kara terrane and Taimyr are very likely candidates for the Neoproterozoic and Paleozoic zircons. Therefore we suggest that collision between Siberia and the Kara terrane took place in the Late Visean, and that this newly formed orogen was the important source for the studied Carboniferous clastic.

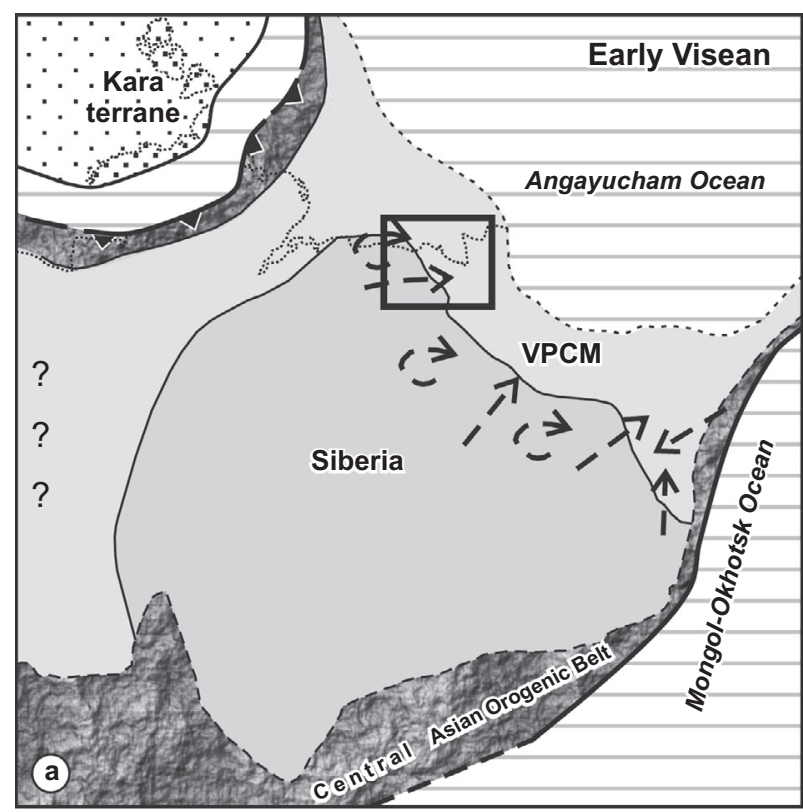

Hing Highland

Lowland

Shelf

Accreted terrane

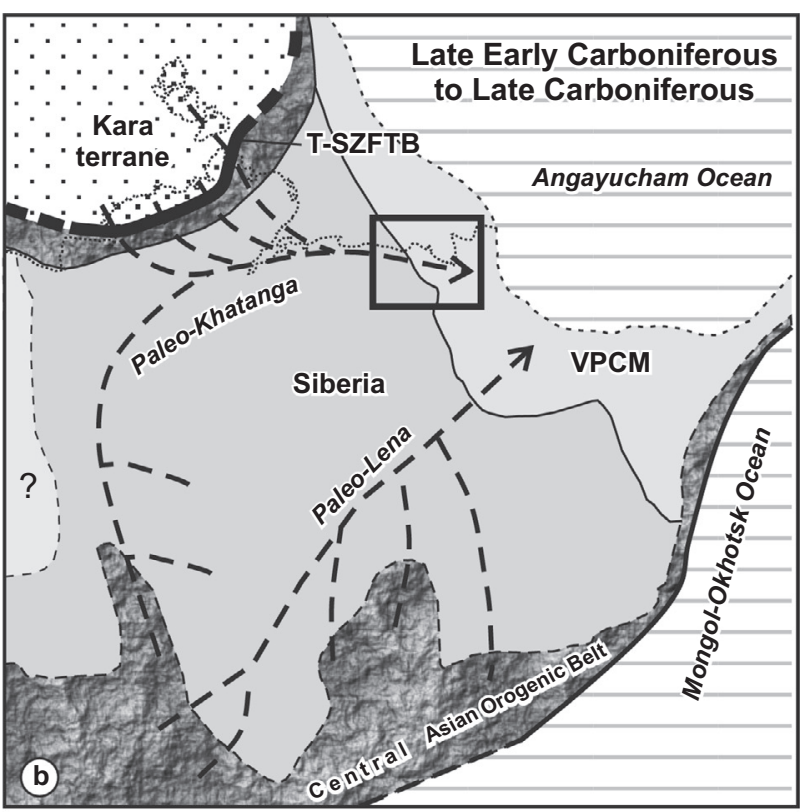

Oceanic crust

Subduction zone

Inferred river systems transporting clastic material

T-SZFTB - Taimyr-Severnaya Zemlya Fold and Thrust Belt VPCM - Verkhoyansk passive continental margin

Fig. 11. Provenance restoration: a - Early Visean. b - Late Visean - Late Carboniferous (after Ershova et al., 2013; Prokopiev et al., 2013 modified). 


\subsection{Paleogeographical implication}

Sediment transport pathways during the Carboniferous across Siberia were controlled by several main physiographic features. Firstly, sparse data about Carboniferous rocks to the west from Siberian Craton point to the existence of a marine basin to the west of the Siberian continent during Early-Middle Carboniferous time (Yolkin et al., 2001). Secondly, a passive margin (the Verkhoyansk passive margin) existed along the eastern margin of the Siberian continent (Parfenov, 1991; Prokopiev et al., 2001). Thirdly, the Vilyui Depression formed as a result of Late Devonian rifting (Gaiduk, 1988) and represented a major depocentre for sediments supplied from southern Siberia and the surrounding fold belts.

Thus the studied deposits formed in the northeastern passive margin of Siberia and sediments could have been transported only by relatively big river system flowing down from western part of the continent. Studies done on modern river systems such as those by Amidon et al. (2005a, 2005b) on modern Himalayan rivers, by Craddock and Kylander-Clark (2013) on Tertiary Mississippi River Delta, Safonova et al. (2010) on modern Amur and Yenisey rivers, etc., show a multiple mixing of sediments for river systems draining huge regions. We suggest that our $\mathrm{U} / \mathrm{Pb}$ data point to existence of large Carboniferous river systems within the Siberia continent that drained multiple distal provenance areas.

According to Prokopiev et al. (2008), the Paleo-Lena River flowed along the axis of the Vilyui Depression, transporting sediments from southwestern Siberia and CAOB to the central part of the Verkhoyansk passive margin. From the results of this study, we propose that another major fluvial system (the Paleo-Khatanga) was the main sediment transport pathway along the part western and northern part of Siberia, transporting sediments to the northern part of the Verkhoyansk passive margin (Fig. 11b).

\section{Conclusions}

Data presented here suggest a change in provenance across the Early Visean - Late Visean boundary within the northeastern margin of Siberia. This change is interpreted as a shift from sources within the basement of the Siberian craton and other local sources to a more distal provenance outside of the Siberian Platform (Fig. 11).

Based on the zircon ages, we suggest that the most likely provenance areas for the studied Late Visean - Late Carboniferous succession were located within the Taimyr - Severnaya Zemlya FTB, southwest of Siberia and CAOB. The indication that the Kara terrane is a source region suggests the timing of collision between Kara and Siberia should be placed at the Late Visean that earlier than it was previously assumed (Late Carboniferous - Permian). Our paleogeographic model illustrates the existence of at least two major fluvial systems draining eastward across Siberia during the Carboniferous: the Paleo-Lena in the south and the Paleo-Khatanga in the north. A newly formed fold belt along the northern margin of Siberia formed the main watershed for the Paleo-Khatanga, which could also possibly have had a tributary system that carried sediments from the southwestern margins of Siberia and the CAOB. The Paleo-Khatanga River was therefore the main conduit supplying sediments to the northern part of the Verkhoyansk passive margin.

\section{Acknowledgements}

This research was supported by RFBR grants N 13-05-00700, 13-05-00943, research grant of Saint Petersburg State University
N 3.39.139.2014, DPMGI SB RAS N VIII.66.1.4, Program ONZ-10.2, Project N 53 (Program RAS N 2). Analytical costs for 07AP02, 07AP67 samples was funded by British Petroleum and by NSF-EAR 0948673 awarded to E.L. Miller. Fieldwork in 2009 was supported by TGS NOPEC Geophysical Company. This paper is a contribution to IGCP\#592. Fruitful discussions with E.L. Miller helped to make our ideas more concise. Reviews by Inna Safonova, Larry Lane and Owen Anfinson greatly improved the figures and text.

\section{Appendix A. Supplementary material}

Supplementary data associated with this article can be found, in the online version, at http://dx.doi.org/10.1016/j.jseaes.2015.04. 046 .

\section{References}

Abramov, B.S., Grigorieva, A.D., 1983. Biostratigraphy and brachiopods of the Middle and Upper Carboniferous deposits of Verkhoyansk region. Nauka, Moscow. [in Russian].

Abramov, B.S., Grigorieva, A.D., 1986. Biostratigraphy and brachiopods of the Lowe Carboniferous deposits of Verkhoyansk region. Nauka, Moscow. [in Russian].

Amidon, W.H., Burbank, D.W., Gehrels, G.E., 2005a. U-Pb zircon ages as a sediment mixing tracer in the Nepal Himalaya. Earth Planetary Sci. Lett. 235, 244-260.

Amidon, W.H., Burbank, D.W., Gehrels, G.E., 2005b. Construction of detrital mineral populations-Insights from mixing of $\mathrm{U}-\mathrm{Pb}$ zircon ages in Himalayan rivers. Basin Res. 17, 463-485.

Bogush, O.I., Gerasimov, E.K., Cherniak, G.E., Yuferov, O.V., 1963. Krestyahskie conglomerates in the mouth of the Lena R., and their analogs. Doklady AN SSSR 153 (1), 166-169 [in Russian].

Bulgakova, M.D., 1967. Krestyahskie conglomerates of the Lena R. Delta and the conditions of their formation. Litologiya i poleznye iskopaemye 3, 127-134 [in Russian].

Cocks, L.R.M., Torsvik, T.H., 2007. Siberia, the wandering northern terrane, and its changing geography through the Palaeozoic. Earth-Sci. Rev. 82, 29-74.

Condie, K.C., 1993. Chemical composition and evolution of the upper continental crust: contrasting results from surface samples and shales. Chem. Geol. 104, 137.

Craddock, W.H., Kylander-Clark, A.R.C., 2013. U-Pb ages of detrital zircons from the Tertiary Mississippi River Delta in central Louisiana: Insights into sediment provenance. Geosphere 9 (6), 1832-1851. Available from: <http://geosphere. gsapubs.org/content/early/2013/11/13/GES00917.1.abstract 2013! >.

Dickinson, W.R., 1970. Interpreting detrital modes of graywacke and arkose. J. Sed. Petrology 40, 695-707.

Dickinson, W.R., Bead, L.S., Brakenridge, G.R., Erjavec, J.L., Ferguson, R.C., Inman, K.F. Knepp, R.A., Lindberg, F.A., Ryberg, P.T., 1983. Provenance of North American Phanerozoic sandstones in relation to tectonic setting. Geol. Soc. Am. Bull. 94 222-235.

Ershova, V.B., Khudoley, A.K., Prokopiev, A.V., 2013. Reconstruction of provenances and tectonic events in the Carboniferous in the northeastern framing of the Siberian platform from U-Pb dating of detrital zircon. Geotectonics 47 (2), $93-$ 100.

Ershova, V.B., Khudoley, A.K., Prokopiev, A.V., 2014. Early Visean paleogeography of northern Siberia: new evidence of rift to drift transition along the eastern margin of Siberia. J. Asian Earth Sci. 91, 206-217.

Gaiduk, V.V., 1988. Vilyui Middle Paleozoic Rift System. Yakutian branch of Academy of Sciences of the USSR, Yakutsk, 128 p.

Gazzi, P., 1966. Le Arenarie del Flysch Sopracretaceo dell'Appennino Modenese: Correlazioni con il Flysch di Monghidoro. Mineralogica e Petrografica Acta 12 69-97.

Gehrels, G.E., 2012. Detrital zircon U-Pb geochronology: current methods and new opportunities. In: Busby, C., Azor, A. (Eds.), Tectonics of Sedimentary Basins: Recent Advances. Blackwell Publishing Ltd., pp. 47-62, Chapter 2.

Gehrels, G.E., Valencia, V.A. Ruiz, J., 2008. Enhanced precision, accuracy, efficiency, and spatial resolution of $\mathrm{U}-\mathrm{Pb}$ ages by laser ablation-multicollector-inductively coupled plasma-mass spectrometry. Geochem., Geophys., Geosyst. 9 (3), art. no. Q03017.

Glorie, S., Buslov, M., Zhimulev, F., Safonova, I., 2014. Provenance of Early Paleozoic sediments at the southwestern margin if the Siberian Craton: insights from detrital zircon U-Pb geochronology. J. Asian Earth Sci. 82, 115-123.

Glorie, S., De Grave, J., Buslov, M.M., Zhimulev, F.I., Izmer, A., Vandoorne, W. Ryabinin, A., Van den Haute, P., Vanhaecke, F., Elburg, M.A., 2011. Formation and Palaeozoic evolution of the Gorny-Altai-Altai-Mongolia suture zone (South Siberia): Zircon U/Pb constraints on the igneous record. Gondwana Res. 20, 465-484.

Grausman, V.V., 1995. Geological section of the Ust-Olenyek wells. 2370 (int. 36052700). Tikhookeanskaya Geologiya 14 (4), 137-140 [in Russian]. 
Gu, X.X., Liu, J.M., Zheng, M.H., Tang, J.X., Qi, L., 2002. Provenance and tectonic setting of the Proterozoic turbidites in Hunan, South China: geochemical evidence. J. Sediment. Res. 72, 393-407.

Gusev, N.I., Rudenko, V.E., Berezhnaya, N.G., Skublov, S.G., Larionov, A.N., 2013. Isotopic-geochemical characteristics and the age (SHRIMP-II) of metamorphic and magmatic rocks in the Kotuikan-Monkhola zone of the Anabar Shield. Reg. Geol. Metall. 54, 45-59 (in Russian).

Harris, D.B., Toro, J., Prokopiev, A.V., 2013. Detrital zircon U-Pb geochronology of Mesozoic sandstones from the Lower Yana River, northern Russia. Lithosphere 5 (1), 98-108.

Ingersoll, R.V., Bulard, T.F., Ford, R.L., Grimn, J.P., Pickle, J.P., Sares, S.W., 1984. The effect of grain size on detrital modes: a test of the Gazzi-Dickinson Point Counting method. J. Sediment. Petrol. 54, 103-116.

Khudoley, A., Chamberlain, K., Ershova, V., Sears, J., Prokopiev, A., MacLean, J. Kazakova, G., Malyshev, S., Molchanov, A., Kullerud, K., Toro, J., Miller, E., Veselovskiy, R., Li, A., Chipley, D., 2015. Proterozoic supercontinental restorations: constraints from provenance studies of Mesoproterozoic to Cambrian clastic rocks, eastern Siberian Craton. Precambrian Res. 259, 78-94.

Khudoley, A.K., Rainbird, R.H., Stern, R.A., Kropachev, A.P., Heaman, L.M., Zanin, A.M., Podkovyrov, V.N., Belova, V.N., Sukhorukov, V.I., 2001. Sedimentary evolution of the Riphean - Vendian Basin of Southeastern Siberia. Precambrian Res. 111, 129-163.

Kröner, A., Kovach, V., Belousova, E., Hegner, E., Armstrong, R., Dolgopolova, A., Seltmann, R., Alexeiev, D.V., Hoffmann, J.E., Wong, J., Sun, M., Cai, K., Wang, T. Tong, Y., Wilde, S.A., Degtyarev, K.E., Rytsk, E., 2014. Reassessment of continental growth during the accretionary history of the Central Asian Orogenic Belt. Gondwana Res. 25, 103-125.

Lorenz, H., Gee, D.G., Simonetti, A., 2008. Detrital zircon ages and provenance of the Late Neoproterozoic and Palaeozoic successions on Severnaya Zemlya, Kara Shelf: a tie to Baltica. Norwegian J. Geol. 88 (4), 235-258.

Lorenz, H., Gee, D.G., Whitehous, M., 2007. New geochronological data on Palaeozoic igneous activity and deformation in the Severnaya Zemlya Archipelago, Russia, and implications for the development of the Eurasian Arctic margin. Geol. Magaz. 144, 105-125.

Makariev, A.A. (Ed.), 2013. State Geological Map of the Russian Federation. Scale $1: 1000000$ (third generation). Sheet T-45 - 48th. Chelyuskin. Explanatory Note. St. Petersburg.: VSEGEI, 2012. [in Russian].

Malich, N.S. (Ed.), 1999. Geological Map of Siberian Platform and Adjoining Areas. Scale 1:1500000 (9 sheets). St. Petersburg, VSEGEI Press. [in Russian]

McLennan, S.M., 1989. Rare earth elements in sedimentary rocks: influence of provenance and sedimentary processes. In: Lipin, B.R., McKay, G.A. (Eds.) Geochemistry and Mineralogy of Rare Earth Elements. Mineralogical Society of America, Reviews in Mineralogy, vol. 21, pp. 169-200.

McLennan, S.M., Bock, B., Hemming, S.R., Hurowitz, J.A., Lev, S.M., McDaniel, D.K. 2003. The role of provenance and sedimentary processes in the geochemistry of sedimentary rocks. In: Lentz, D. (Ed.), Geochemistry of Sediments and Sedimentary Rocks: Evolutionary Considerations to Mineral Deposit-Forming Environments. St. John's, Geological Association of Canada, pp. 7-38.

McLennan, S.M., Hemming, S.R., McDaniel, D.K., Hanson, G.N., 1993. Geochemical approaches to sedimentation, provenance, and tectonics. In: Johnson, M.J., Basu, A. (Eds.), Processes Controlling the Composition of Clastic Sediments. Geological Society of America. Special Paper 284, pp. 21-40.

Menner, V.V., Sidyachenko, A.I., 1975. Upper Devonian of the lower reaches of the river Lena. Doklady AN SSSR 220 (1), 178-181 [in Russian].

Metelkin, D.V., Vernikovsky, V.A., Kazansky, A.Yu., Bogolepova, O.K., Gubanov, A.P., 2005. Paleozoic history of the Kara microcontinent and its relation to Siberia and Baltica: paleomagnetism, paleogeography and tectonics. Tectonophysics 398, 225-243.

Mezhvilk, A.A., 1956. Molasses in the Lena R. delta. Doklady AN SSSR 108 (3), 317 319 [in Russian].

Miller, E.L., Soloviev, A.V., Prokopiev, A.V., Toro, J., Harris, D., Kuzmichev, A.B. Gehrels, G.E., 2013. Triassic river systems and the paleo-Pacific margin of northwestern Pangea. Gondwana Res. 23 (4), 1631-1645.

Miller, E.L., Toro, J., Gehrels, G., Amato, J.M., Prokopiev, A.V., Tuchkova, M.I., Akinin, V.V., Dumitru, T.A., Moore, T.E., Cecile, M.P., 2006. New insights into Arctic paleogeography and tectonics from $\mathrm{U}-\mathrm{Pb}$ detrital zircon geochronology. Tectonics 25 (3), art. no. TC3013.

Parfenov, L.M., 1991. Tectonics of the Verkhoyansk-Kolyma Mesozoides in the context of plate tectonics. Tectonophysics 139, 319-342.

Parfenov, L.M., Badarch, G., Berzin, N.A., Khanchuk, A.I., Kuzmin, M.I., Nokleberg, W.J., Prokopiev, A.V., Ogasawara, M., Yan, H., 2009. Summary of Northeast Asia geodynamics and tectonics. Stephan Mueller Spec. Publ. Ser. 4, 11-33.

Parfenov, L.M., Berzin, N.A., Khanchuk, A.I., Badarch, G., Belichenko, V.G., Bulgatov, A.N., Dril', S.I., Kirillova, G.L., Kuz'min, M.I., Nokleberg, W., Prokopiev, A.V. Timofeev, V.F., Tomurtogoo, O., Yan, H., 2003. Model for the formation of orogenic belts of Central and Northeast Asia. Tikhookeanskaya Geologiya 6, 7 42 [in Russian].

Pease, V., Gee, D.G., Vernikovsky, V., Vernikovskaya, A., Kireev, S., 2001. Geochronological evidence for late-Grenvillian magmatic and metamorphic events in Central Taimyr, northern Siberia. Terra Nova 13, 270-280.
Pease, V., Scott, R.A., 2009. Crustal affinities in the Arctic Uralides, northern Russia: significance of detrital zircon ages from Neoproterozoic and Palaeozoic sediments in Novaya Zemlya and Taimyr. J. Geol. Soc. 166, 517-527.

Pease, V., Vernikovsky, V., 1998. The tectonomagmatic evolution of the Taimyr Peninsula: further constraints from new ion-microprobe data. Polarforschung 68, 171-178.

Pettijohn, F.J., Potter, P.E., Siever, R., 1987. Sand and Sandstone, 2nd ed. SpringerVerlag.

Pogrebitsky, Y.E. (Ed.), 1998. Geological State Map of the Russian Federation. 1:1000000 scale, S-47-49 sheet (Taimyr Lake). Map and Explanation text. SaintPetersburg, VSEGEI press, 231 p. [in Russian].

Prokopiev, A.V., Ershova, V.B., Miller, E.L., Khudoley, A.K., 2013. Early Carboniferous paleogeography of the northern Verkhoyansk passive margin as derived from $\mathrm{U}-\mathrm{Pb}$ dating of detrital zircons: role of erosion products of the Central Asian and Taimyr-Severnaya Zemlya fold belts. Russian Geol. Geophys. 54 (10), 11951204.

Prokopiev, A.V., Parfenov, L.M., Tomshin, M.D., Kolodeznikov, I.I., 2001. Sedimentary cover of the Siberian platform and adjacent fold-and-thrust belts. In: Parfenov, L.M., Kuzmin, M.I (Eds.), Tectonics, geodynamics and metallogeny of the territory of the Sakha Republic (Yakutia), pp. 113-155. [in Russian].

Prokopiev, A.V., Toro, J., Miller, E.L., Gehrels, G.E., 2008. The paleo-Lena River - 200 m.y. of transcontinental zircon transport in Siberia. Geology 36 (9), 699-702.

Prokopiev, A.V., Toro, J., Smelov, A.P., Miller, E.L., Wooden, J., Grakhanov, S.A., Oleinikov, O.B., 2007. Ust'-Lena metamorphic complex (northeast Asia): first U$\mathrm{Pb}$ SHRIMP geochronological data. Otechestvennaya Geologiya 5, 26-30 [in Russian].

Rojas-Agramonte, Y., Kröner, A., Alexeiev, D.V., Jeffreys, T., Khudoley, A.K., Wong, J., Geng, H., Shu, L., Semiletkin, S.A., Mikolaichuk, A.V., Kiselev, V.V., Yiang, J., Seltmann, R., 2014. Detrital and igneous zircon ages for supracrustal rocks of the Kyrgyz Tianshan and palaeogeographic implications. Gondwana Res. 26 (34), 957-974

Rohas-Agramonte, Y., Kroner, A., Demoux, A., Xia, X., Wang, W., Donskaya, T., Liu, D., Sun, M., 2011. Detrital and xenocrystic zircon ages from Neoproterozoic to Palaeozoic arc terranes of Mongolia: Significance for the origin of crustal fragments in the Central Asian Orogenic Belt. Gondwana Res. 19, 751-763.

Rozen, O.M., 2003. Siberian craton: tectonic zonation, stages of evolution. Geotectonics 37 (3), 175-192.

Rudnev, S.N., 2013. Early Paleozoic Granitoid Magmatism of the Altai-Sayan Folded Area and the Ozernaya Zone of West Mongolia. Publishing House of the Siberian Branch of the RAS, Novosibirsk [in Russian].

Safonova, I., Maruyama, S., Hirata, T., Kon, Y., Rino, S., 2010. LA ICP MS U-Pb ages of detrital zircons from Russia largest rivers: implications for major granitoid events in Eurasia and global episodes of supercontinent formation. J. Geodynam. 50, 134-153.

Safonova, I., Seltmann, R., Kroener, A., Gladkochub, D., Schulmann, K., Xiao, W., Kim, T., Komiya, T., Sun, M., 2011. A new concept of continental construction in the Central Asian Orogenic Belt: (Compared to actualistic examples from the Western Pacific). Episodes 34 (2), 1-10.

Smelov, A.P., Timofeev, V.F., 2007. The age of the North Asian Cratonic basement: an overview. Gondwana Res. 12, 279-288.

Taylor, S.R., McLennan, S.M., 1985. The Continental Crust: Its Composition and Evolution. Blackwell, Cambridge.

Vernikovsky, V.A., 1996. Geodynamic Evolution of the Taimyr Folded Region. Publishing House of the Siberian Division of RAS, Novosibirsk [in Russian].

Vernikovsky, V.A., Metelkin, D.V., Vernikovskaya, A.E., Sal'Nikova, E.B., Kovach, V.P., Kotov, A.B., 2001. The oldest island arc complex of Taimyr: concerning the issue of the Central-Taimyr accretionary belt formation and paleogeodynamic reconstructions in the arctic. Doklady Earth Sci. 436 (2), 186-192.

Vernikovsky, V.A., Vernikovskaya, A.E., 2001. Central Taimyr accretionary belt (Arctic Asia): Meso-Neoproterozoic tectonic evolution and Rodinia breakup Precambrian Res. 110, 127-141.

Vernikovsky, V.A., Vernikovskaya, A.E., Pease, V.L., Gee, D.G., 2004. Neoproterozoic orogeny along the margins of Siberia. In: Gee, D.G., Pease, V.L. (Eds.), The Neoproterozoic Timanide Orogen of Eastern Baltica. Geological Society, London, pp. 233-247.

Windley, B.F., Alexeiev, D., Xiao, W., Kroner, A., Badarch, G., 2007. Tectonic models for accretion of the Central Asian Orogenic Belt. J. Geol. Soc. London 164, 31-47.

Wingate, M.T.D., Pisarevsky, S.A., Gladkochub, D.P., Donskaya, T.V., Konstantinov, K.M., Mazukabzov, A.M., Stanevich, A.M., 2009. Geochronology and paleomagnetism of mafic igneous rocks in the Olenek Uplift, northern Siberia: implications for Mesoproterozoic supercontinents and paleogeography. Precambrian Res. 170, 256-266.

Yolkin, E.A., Krasnov, V.I., Bakharev, N.K., Belova, E.V., Dubatov, V.N., Izokh, N.G., Klets, A.G., Kontorovich, A.E., Peregoedov, L.G., Sennikov, N.V., Timokhina, I.G., Kromykh, V.G., 2001. Stratigraphy of oil and gas basins of Siberia. Western Siberia. Publishing house of SB RAS, Novosibirsk [in Russian].

Zakharov, Yu.I., Chukhonin, V.F., Proskurnin, V.F., 1993. New isotope-geochemical data for granitoids of the Shrenk-Mamont protrusion of Taimyr peninsula. Doklady AN SSSR 332 (1), 58-61 [in Russian]. 